\title{
杭に作用する間げき水圧の一計算法*
}

\section{A BASIC STUDY FOR PORE WATER PRESSURE ON A PILE DRIVEN IN CLAY}

西田 義 親**

By Yoshichika Nishida

\section{1. 緒論}

粘土地盤に打ち込まれた杭の支持力は, 時間とともに 変化し, 長時間たったのちは支持力は一般に増加する。 この現象は,一つには杭の打込みによって乱された粘土 が強度を回復するためであり，他の原因は，杭の打込み によって地般の中に生じた間げき水圧の消失によって， いわゆる有効応力が増大するためと思われる。地盤に打 ち込まれた杭は, ある範囲内の粘土を破䏅し, 乱し, 上 下方向や横方向に変形させ, ある場合には圧縮する。し かしながら，問題の取り扱いを簡単にし基本的な計算を 行なう第一段階として, 杭は土を水平方向のみに圧し て, 鉛直方向の垂直応力に変化はないものと仮定して計 算をすすめることは十分許されると思う。したがって， この計算は比較的長い摩擦杭の中間部分に応用されるべ きだと思われる。もちろん，実際的な見地から，若干の 仮定を用いることになる。

\section{2. 基 本 $\odot$ 式}

杭は地盤に鉛直に打ち込まれているものとし，杭の断 面の中心で地表面にあるものを原点とし, 鉛直方向を $z$ 軸とする円柱座標 $(r, t, z)$ を用いる。杭の周囲の地盤 に生じる応力成分のつり台いの式はつぎのようになる。

$$
\begin{aligned}
& \frac{\partial \sigma_{r}}{\partial r}+\frac{\partial \tau}{\partial z}+\frac{\sigma_{r}-\sigma_{t}}{r}=0 . \\
& \frac{\partial \sigma_{z}}{\partial z}+\frac{\partial \tau}{\partial r}+\frac{\tau}{r}+r=0 \cdots .
\end{aligned}
$$

ここに $\sigma_{r}, \sigma_{t}, \sigma_{z}$ はそれぞれ $r, t, z$ 方向の垂直応力 で, $\tau$ はせん断応力である。

\section{(図一1 参照)。}

杭から離れたところの自然の状態の地盤の鉛直方向の 垂直応力は

$$
\sigma_{z}=r z
$$

となる。さて杭のまわりの地盤は水平方向のみに圧せら れると仮定しているのであるから， $\sigma_{r}>\sigma_{t}$ と考えること は罗当だと思われる。もちろん, 三垂直応力 $\sigma_{r}, \sigma_{t}$, $\sigma_{\boldsymbol{z}}$ は㛜密な意味では主応力でないけれども, 問題の取 り扱いを簡単にするため, せん断応力ては生じないと考

*アジア土質基礎会議 (1963) で一部発表

** 正員 工博 金沢大学工学部 土木工学科
えることは許されるべきである。

杭から離れたところの地盤は弾性的に作動するものと 考えるなら，式 (1) を満たす解はつぎのようになる。

$$
\begin{aligned}
& \sigma_{r}=c_{1}+c_{2} \frac{1}{r^{2}}+(1+2 \log r) c_{3} \\
& \sigma_{t}=c_{1}-c_{2} \frac{1}{r^{2}}+(3+2 \log r) c_{3} .
\end{aligned}
$$

ここに $c_{1}, c_{2} c_{3}$ は積分常数である。杭から遠方 $(r=$ の）の自然状態の地盤では，水平の垂直応力はともに静 止土圧に等しいという条件を適用するとつぎの結果を得 る。

$$
\begin{aligned}
& \sigma_{r}=\kappa_{0} r z+c_{2} / r^{2} \\
& \sigma_{t}=\kappa_{0} r z-c_{2} / r^{2}
\end{aligned}
$$

ただし弾性ひずみの関係 は $\kappa_{0}=1 / m-1$ の場合を 除き $r=\infty$ で水平ひずみ がないという条件を満た さないが, 応力のつり合 いは完全に満たす。ここ に $\kappa_{0}$ は静止土圧数係, $m$ はポアソン数である。 $\sigma_{z}$

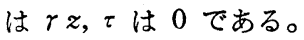
杭に接近するにつれて， 半径方向の 垂直応力 $\sigma_{r}$ は增大し, 円周方向の垂 直応力 $\sigma_{t}$ は減少する。 しかしながら,ての $\sigma_{r}$ と $\sigma_{t}$ との関係は, 粘土の 強度から定まるあ る一定の限度を越 えることができな い。そこでいま， 杭からある一定の 距離 $r=R$ で地盤 が破壊状態になっ ていると考光，て

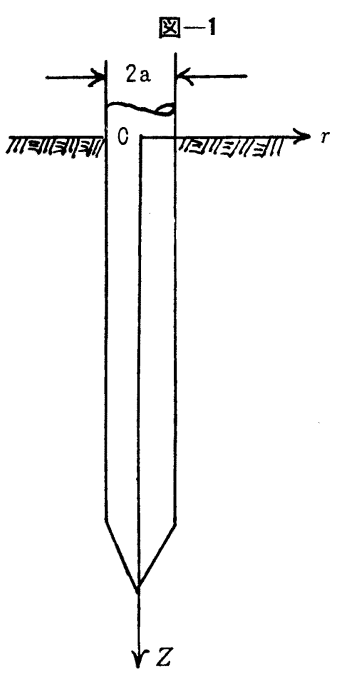

図-2

のところで Mohr の条件 $\sigma_{r}-\sigma_{t}=2 c_{u}$ (ただし $c_{u}$ は粘 土の非排水試験で得た粘着力）を用いると, 式 (6), (7) のうちの常数が決定できる(図一2 参照)。 


$$
\begin{gathered}
\sigma_{r}=\kappa_{0} r z+c_{u} \frac{R^{2}}{r^{2}} \\
\sigma_{t}=\kappa_{0} r z-c_{u} \frac{R^{2}}{r^{2}}
\end{gathered}
$$

これは内圧をうけた中空円筒に生じる応力をあたえる 式と同様で， $r \geqq R$ の範囲に成立する。地表 $z=0$ では $\sigma_{r}$ は最大でも $c_{u}, \sigma_{t}$ は最少でも $-c_{u}$ となる。したが って，硚は受動土圧より小で， $\sigma_{t}$ は主動土圧より大で あって土圧論からみても合理的である。

\section{3. 杭の近くの地盤内の応力}

杭の付近のある範囲内の地盤の粘土は常に破壊されて いるから， $r \leqq R$ の範囲では，破壊の条件がいたるとこ ろで成立しているはずである。いま，この $r \leqq R$ 内の地 盤内の水平垂直応力を $\sigma_{r}{ }^{\prime}, \sigma_{t}{ }^{\prime}$ とすると, $\sigma_{r}{ }^{\prime}-\sigma_{t}{ }^{\prime}=2 c_{u}$ なる条件を式 (1) に代入して積分し（もちろん $\tau=0$ 之 仮定している）て $\sigma_{r^{\prime}}{ }^{\prime}, \sigma_{t}{ }^{\prime}$ を求め， $r=R$ の境界で，そ れぞれ式 (8)，(9)の $\sigma_{r} ， \sigma_{t}$ 亿等しいとおいて積分常 数を決めるとつぎの結果を得る。

$$
\begin{aligned}
& \sigma_{r}{ }^{\prime}=\kappa_{0} r z+c_{u}\left\{2 \log \frac{R}{r}+1\right\} \\
& \sigma_{t}{ }^{\prime}=\kappa_{0} r z+c_{u}\left\{2 \log \frac{R}{r}-1\right\}
\end{aligned}
$$

もちろん，乙てでも $\sigma_{z}=r z$ と仮定している。 $R$ は末知 の常数で, 土の変形の条件から決定すべきものである。

\section{4. 粘 土の变 形}

杭を打ち込む前の自然の状態の地盤にくらべると, 杭 を打ち込んだあとで土が水平方向に圧せられたときに生 じた応力の変化は, 式 (8), (9), (10), (11) からつぎ のようになる。

$r \geqq R$ なる弾性域では

$$
\begin{aligned}
& \Delta \sigma_{r}=c_{u} \frac{R^{2}}{r^{2}} \cdots \\
& \Delta \sigma_{t}=-c_{u} \frac{R^{2}}{r^{2}}
\end{aligned}
$$

$r \leqq R$ なる破壊域では

$$
\begin{aligned}
& \Delta \sigma_{r}{ }^{\prime}=c_{u}\left\{2 \log \frac{R}{r}+1\right\} \\
& \Delta \sigma_{t}{ }^{\prime}=c_{u}\left\{2 \log \frac{R}{r}-1\right\}
\end{aligned}
$$

鉛直方向の垂直応力 $\sigma_{z}$ には変化がないと仮定している。

杭が地盤に打ち込まれるためには，杭の体積に相当す る土の圧縮または，変位がなければならない。かって筆 者は上の各式にふくまれる末知の常数 $R$ を, 土の圧縮

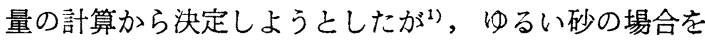
除いては妥当とはいえず，特に飽和した粘土地盤の場合 などには，土の水平方向の変位を考えて $R$ を計算した ほうが合理的と思われる。との場合の計算に必要な応力 とひずみとの関係については, 種々の議論があるけれど
も，他に適当な方法のない以上，弾性論を準用して，土 の場合にも応力とひずみが比例すると一応仮定して計算 をすすめることは許されると思う。いま地盤の土のヤン グ係数を $E$ ，ポアソン比 $1 / m$ をとすると， $r \geqq R$ なる 末破壊の弾性域で，式 (12)，(13）で示されるような応 力変化のあった場合，地盤の水平半径方向の変位は $\rho_{r}$ $=(m+1) c_{u} R^{2} / m E r$ となるから ${ }^{2)} r=R$ なる弾性域と破 壊域との境界における水平半径方向の変位はつぎのよう になる。

$$
\rho_{R}=(m+1) c_{u} R / \mathrm{m} E
$$

式 (14)，(15）で示されるような応力の変化を生じた 杭の近くの破壊域 $(a \leqq r \leqq R)$ における水平半径方向の 土のひずみは $\varepsilon_{r}=\left(\Delta \sigma_{r}{ }^{\prime}-\Delta \sigma_{t}{ }^{\prime} / \mathrm{m}\right) / E$ となるから,半径 $a$ なる杭が地盤に打ち込まれ，杭の体積に相当する土の変 位があった場合，つぎの関係が成立する（杭の単位長に つ)。

$$
\begin{aligned}
& \pi a^{2}=2 \pi R \rho_{R}+\int_{a}^{R} 2 \pi r \varepsilon_{r} d r \\
& =\frac{m+1}{m} \frac{c_{u}}{E} 2 \pi R^{2}+\int_{a}^{R} \frac{c_{u}}{E}\left\{\frac{m-1}{m} 2 \log \frac{R}{r}+\frac{m+1}{m}\right\} 2 \pi r d r
\end{aligned}
$$

$$
\therefore \frac{E}{c_{u}}=\frac{2(2 m+1)}{m} \frac{R^{2}}{a^{2}}-\frac{2(m-1)}{m} \log \frac{R}{a}-2
$$

しがって，もし地盤の土の $E, c_{u}, 1 / m$ が与えられる なら, 破壊域の大きさ $R$ が杭径の何倍という形で求ま るのである。いま考えているような飽和した粘土地盤の 場合には当然，ポアソン比は $0.5(m=2)$ としてよい。

\section{5. 過剩（初期）間げき水圧}

飽和した粘土に三軸応力 $\Delta \sigma_{1}, \Delta \sigma_{2}, \Delta \sigma_{3}$ を加えたとき 生じる間げき水圧 $\Delta u$ は Henkel によってつぎのよう に示される3゙。

$$
\begin{aligned}
\Delta u & =\frac{1}{3}\left(\Delta \sigma_{1}+\Delta \sigma_{2}+\Delta \sigma_{3}\right) \\
& +\alpha \sqrt{\left(\Delta \sigma_{1}-\Delta \sigma_{2}\right)^{2}+\left(\Delta \sigma_{2}-\Delta \sigma_{3}\right)^{2}+\left(\Delta \sigma_{3}-\Delta \sigma_{1}\right)^{2}}
\end{aligned}
$$

ただし めは倸数で Skempton の間げき水圧係数 $A$ との 間に

$$
\alpha=\left(A-\frac{1}{3}\right) / \sqrt{2}
$$

なる関係がある

杭を地盤に打ち込んだ場合，自然の状態にくらべて， 式 (12)，(13)，(14)，(15）で示されるような応力変化 が生じるが，粘土地盤はすぐには排水を許さないから， この応力変化は, 新たな間げき水圧の発生する原因とな る。したがって式 (18)，(19）を用いて， $\Delta \sigma_{r}, \Delta \sigma_{t}, \Delta \sigma_{r}{ }^{\prime}$ ， $\Delta \sigma_{t}{ }^{\prime}, \Delta \sigma_{z}\left(=\Delta \sigma_{z}{ }^{\prime}=0\right)$ をそれぞれ三軸方向の主応力の変 化として計算するとつぎのようになる。

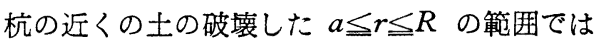




$$
\Delta u=c_{u}\left\{\frac{4}{3} \log \frac{R}{r}+\left(A-\frac{1}{3}\right) \sqrt{3+4\left(\log \frac{R}{r}\right)^{2}}\right\}
$$

杭より離れたところの $r \geqq R$ なる弾性域で注

$$
\Delta u=c_{u}\left(A-\frac{1}{3}\right) \sqrt{3} R^{2} / r^{2}
$$

したがって, 実験で求める $A, c_{u}$, 式 $(17)^{\prime}$ から与えら れる $R$ が判明するなら式 (20)，(21) によって，杭の 周囲の地盤内の任意の距離の点に生じる (初期) 間げき 水圧が計算できる。

\section{6. 計 算 例}

杭によって破壊される土の䈥围の訫算には土のヤング 係数 $E$ が必要になる。この $E$ について法振動を利用 して実測した例があり ${ }^{5)}$ ，また土の圧縮注度の $1 / 2$ に相 当する応力とその点のひずみとで求めると述べているも のがあるが ${ }^{6)}$ ，あまり検討されていないようである。飽 和した粘土の三軸非排水圧縮陚験を行なって得た応力ひ ずみ度図について，ヤング係数（初期接線弾性係数）を もとめると，ある特定の間げき比の場合には，側圧に無 関係に一定になることが述べられ，筆者も実験で珰めて いるが,つぎに間げき比 $e$ が変化したときは, $e$ が小さ くなると $E$ が急增し，筆者が広い範囲にわたり種々の 粘土について実験したとてろ, 側圧に無関係にほぼ $e$ 之 $\log _{10} E$ とがある比例関係にあるようである7。土の圧 縮強度 $2 c_{u}$ は密度の関数之考元られるが, 種々の因子 飞影響され，強度と密度は必ずしも平行するものでない ことは含水量の少ない場合に見られるが，特に飽和した 粘土の場合に限るなら，一般的には間げき比の小さいも のが強度は大と考えてよく, $e$ と $\log _{10} 2 c_{u}$ との間に比 例関係があることは従来のべられており，また実験的に も認められている。したがって飽和した粘土の弾性係数 と非排水試験より得た粘着力との間に $E \propto c_{u}$ なる比例 関係が成立する。 $E$ と $c_{u}$ と間には $E=140 c_{u}$ なる関 係があるといわれ，また筆者の実駼結果もほぼてれに一 致した值を与えている ${ }^{8)}$ 。

いま飽和した粘土では $E / c_{u}=50$ 200 とされ9 ，一方 ポアソン比は 0.5 であるから, これらの值を式 (17)'に 代入して計算すると土の破壊される範囲はつぎのように なる。

$$
R / a=3.25 \sim 6.38
$$

この計算は土の初期弾性係数を用いて行なったが, 土 の塑性破壊域を求めるには, 压縮強度に测応する破壊ひ ずみから得た割線弾性係数を用いたほう污より妥当とも 思われる。

実験上の経験によると粘土が破壊する上きのひずみは ほぼ 2 8\% と思われるから，いま平均して仮りに $5 \%$ とするなら $E / c_{u}=20$ となる。乙の值を用いると式(17)' から

$R / a=2.14$
これらの值は Schultze ${ }^{10)}$ の仮定に一つの根拠を与える。 間げき水圧係数 $A$ の值は, もし土が完全な弾性体な らば $1 / 3$ になるのであるが, 実際の土ではその值をとら ず，それぞれの土について実測して求むべきものであ る。鋭敏な粘土では $0.75 \sim 1.5$, 正規圧密粘土では 0.5 〜1.0など実験により Skempton が示している ${ }^{11)}$ 。 そこで, いまてれらの平均の値として仮りに $A=1.0$ と して, 杭の側面に作用する間げき水圧を計算する。式 (20) で $r=a$ とおき, 式 (22),(22)'で得た $R / a=2.14$ 〜6.38 を用いるとつぎの結果を得る。

$$
\Delta u_{r=a}=(2.54 \sim 5.19) c_{u}
$$

$$
\text { ここに } c_{u} \text { は粘土の粘着力である。 }
$$

\section{7. 杭の支持力の増加}

飽和した粘土地盤に打ち込んだ杭のために生じた間げ き水圧は時日が経過するにつれて減少消失し, したがっ て地盤内の有効応力が次第に増加する。乙の時間的変化 については Soderberg ${ }^{12)}$ が考察計算を行なっているが, 初期間げき水圧の分布に検討を要する点があると思われ る。式 (20)，(21) で与えられる間げき水圧は, 杭を打 ち込んだ当初の初期の間げき水圧分布を示すもので，乙 の問題を解く場合の初期条件を与えるととができる。い ま杭を打ち込んだ最初の状態から途中の時間的経過を別 にして, 長期間たったあとで, 杭の支持力がおよそどの くらい増大するかを計算してみよう。

正規圧密された粘土の非排水せん断强度 $c_{\boldsymbol{u}}$ は土かむ りの圧力 $p_{0}$ に比例し, 塑性指数を介して直線関係にあ ることが実験から示されている ${ }^{13)}$ 。間げき水圧の概念を 適用して理論的に計算すると $c_{u}$ と $p_{0}$ との間には，つ ぎの関係がある ${ }^{14)} 。$

$$
\frac{c_{u}}{p_{0}}=\frac{\sin \varphi^{\prime}\left\{\kappa_{0}+A\left(1-\kappa_{0}\right)\right\}}{1+(2 A-1) \sin \varphi^{\prime}}
$$

こてに $\varphi^{\prime}$ は排水試験で得た粘土の内部摩擦角, $A$ は 間げき圧係数， $\kappa_{0}$ は静止土圧係数である。 $\kappa_{0}$ は圧力に あまり関係がなく, 土の性質によって定まるようであ る ${ }^{15)}$ 。計算をすすめるために従来の報告を参考にし $て^{16)}, \kappa_{0} \div 0.65$ 之仮定する。 $\varphi^{\prime}$ は普通は $25 \sim 35^{\circ}$ の值 をとるが，いま $\varphi^{\prime} \doteqdot 30^{\circ}$ と仮定する。式 (23) を求めた とさと同じように $A \div 1$ と考元ることにする。てれら の值を式 (24) に代入し, 土かむりの圧力 $p_{0}=r z$ とす るならつぎのようになる。

$$
c_{u}=0.333 \gamma z \cdots
$$

杭の側面に作用する圧力は式 (10) で $r=a$ として与 えられる。打込み当初作用する有效圧力は $\sigma_{r}{ }^{\prime}-\Delta u$ であるから式 (22)，(22)'，(23)，(25) を用いつぎの ようになる。

$$
\begin{aligned}
\sigma_{r}^{\prime}-\Delta u & =\kappa_{0} r z-c_{u}(0.01 \sim 0.49) \\
& =(0.65 \sim 0.487) r z \cdots .
\end{aligned}
$$


長期間たって間げき水圧が消失したとき杭側面に作用す る有効圧力は, $\Delta u=0$ として

$$
\begin{aligned}
\sigma_{r^{\prime}} & =\kappa_{0} r z+c_{u}(2.53 \sim 4.70) \\
& =(1.49 \sim 2.22) r z \cdots \cdots \cdots
\end{aligned}
$$

となる。

したがって，杭側面における摩摖係数が変化しなけれ ば, 打込み当初の支持力と, 長期閤経過したのちの最終 の支持力との比は式 (26)，(27) からつぎのようになる。

$$
\sigma_{r}{ }^{\prime} /\left(\sigma_{r}{ }^{\prime}-\Delta u\right)=2.29 \sim 4.55
$$

それゆえに，乙の例のような粘土地盤 $\left(E / c_{u}=20\right.$ 〜 200, $A=1.0, \varphi^{\prime}=30^{\circ}, \kappa_{0} \div 0.65 ）$ 亿打ち込まれた摩擦 杭の支持力は，長期間経過す机ば， $2 \sim 4$ 倍に增加する といえる。

\section{8. 実例 टの比較}

打ち込まれた杭によって生じた過剩間げき水压のた め, 支持力が影響をうけることは以前からも推論されて

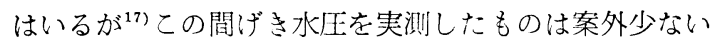
のである。

筆者が鉛直方向の圧力の変化はなく, 土は杭によって 水平にのみ押圧されると仮定した結果, 式 (23) で表わ されるように間げき水圧は深さに無関係に与えられるこ とになるが，このことは，杭のまわりの粘土の含水量を 測って間接的に行なっている議論からも一応罗当之思わ れる ${ }^{18)}$ 。一方，Bjerrum らの間げき水圧の実测結果も， 深さにかかわらず過剩間げき水压は一定であることを示 している ${ }^{199}$ 。しかし一方, Reese らの実測によると ${ }^{20)}$, 過剩間げき水圧は深さとともにいくぶんか增大してい る。それは杭の側面の摩摖（せん断応力）の影響と，も う一つには粘土の䉼着力が深くなるほど若干大きくなっ ているためと思わ机る。その実测に上ると深さ $5 \sim 7 \mathrm{~m}$ のところで過剩間げき水圧は $0.8 \sim 1.2 \mathrm{~kg} / \mathrm{cm}^{2}$ である。 一方, 乙の深さのところの料土の不擋乱非排水粘着力 $c_{u}$ は $0.25 \sim 0.30 \mathrm{~kg} / \mathrm{cm}^{2}$ であるから ${ }^{21)}$, 式 (23) で計 算すると $\Delta u_{r=a}=0.64 \sim 1.55 \mathrm{~kg} / \mathrm{cm}^{2}$ となり，実测にく らべてほぼ罗当な值を与えるようである。

また実测によると，杭半径の 5 ～倍はなれたところ の過剩間げき水圧は, 杭側壁化作用するものの $1 / 4$ 程度 であるという報告がある ${ }^{22)}$ 。杭から半径の $5 \sim 6$ 倍はな れたとてろは，粘土の破壊していない弾性域之考光られ るから, 式 (21) を用いる。式 (22)，(22)'から平均的 飞 $R=4.76 a$ 之仮定し $A \doteqdot 1.0$ を用いると $r=(5 \sim 6) a$ 飞対し $\Delta u=(1.05 \sim 0.725) c_{u}$ となる。一方, 同じ $R$ と $A$ を用い, 式 (20) で轒すると杭の側面においては $\Delta u_{r=a}=4.46 c_{u}$ となる。したがって杭から半径の 5 〜 6 倍はなれたところでは，過剩䦓げき水圧は $1 / 4.25$ 1/6.2 となって実例とほぼ一致するオーダーを与える。 粘土地盤中の杭の支持力が，長期間後いかほど增加する
かを示す二, 三の実例を示すと ${ }^{23)}$, Reese らは打込み直 後にくらべて約 30 日後に 5.4 倍, Eide らは打込み後 3 日目と 800 日目をくらべて 3.75 倍, 最上氏らは 2 時 間目と 5 週間目をくらべて 2.5 倍と与えている。杭の寸 法, 粘土の力学的性質, 排水条件などによって, いろい ろの因子が関係してくるはずであるが，てれらの実例は 筆者が理論的に計算して得た式 (28) が妥当なととを示 している。

上にのべた実例では, 地盤粘土の弾性係数 $E$, 間げ き圧係数 $A$, 内部摩擦角 $\varphi^{\prime}$, 静止土圧係数 $\kappa_{0}$ などが

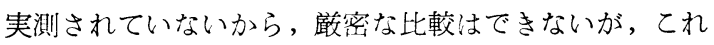
らの值について代表的なものを仮定して行なった計算結 果は, 実際の測定条件や現地の事情を考えるなら, 十分 のオーダーで実例と一致していると判断される。なお, 管杭や $H$ 杭の上うに，杭の排除押圧する土の量が少な いときは式 (17)，(17)'のように半径をそのまま用いる ことができず，また，発生する間げき水圧も小さいとと， はいうまでもなく明白で，実例もこれを示している ${ }^{24)}$

\section{9. 結 論}

飽和した粘土地盤に打ち込まれた杭のために，土が水 平方向にの及押圧されると考えたとき，杭側面に新しく 作用する過剩間げき水圧はその粘土の非排水粘着力の 2.5 5.2 倍である。また長期間たつと杭の支持力は打 込み当初の $2.2 \sim 4.6$ 倍に增加する。乙れらの值はその 粘土の弾性係数之間げき圧係数に大きく関係する。

この研究は 1 本の杭のまわりの間げき水圧について論 じたものであり，また杭を打ち込んだ当初の初期過剩間 げき水圧の計算法を示しているのである。その時間とと もに変化する途中の過程については考察しなかったけれ ぞも, その時間的変化の問題を解く場合の初期条件を与. えるととができる。なお杭と土との間の摩擦がない場合 について基本的な計算を行なったのであるが，もし，乙 の側面摩擦のために地盤内にせん断応力が生じている場 合に生じる間げき水圧の計算は別に報告の準備中であ る。この研究には文部省科学研究費より一部援助をうけ た ${ }^{25)}$ 。なお, Univ. of Florida の F.E. Richart, Jr.(現 Michigan), Lab. Nac. Eng. Civil (Lisbon) の Eng. Rocha 氏らに謝意を表する。

\section{参考 文 献}

1）西田・保田：土木学会論文集, No. 69, p. 38～44 (昭.35) Nishida : Proc. 5th Int. Conf. Soil Mech., Vol. 2. (Paris) (1961) pp. 123 127 等.

2) Bishop el : Proc. Phy. Soc., Vol. 57, p. 1417 (1945)

3) Henkel, D.J. : ASCE Research Conf. Shear Strength of Cohesive Soils, p. 551 (1960)

4) Skempton: Geotechnique, Vol. 10, No. 4, p. 185. (1960)

5) 後藤: 早大理工学部紀要, No. 16, p. 75 (昭.27)

6) Simons : Proc. 4th Int. Conf. Soil Mech., Vol.1, p. 431 (1957) 
7）西田義親：基礎杭の支持力算定に関する研究，pp. 144〜 154 (昭.34)

Barkan : Dynamics of Base and Foundations, pp. 15 １6 (1962)

8) Skempton 外: Proc. 4th Int. Conf. Soil Mech., Vol. 1, p. 105 (1957)

9) Meyerhof: Geotechnique, Vol. 2, p. 314(1950, 1951)

10) Schultze : Annales Inst. Tech. Bat Trav Pub. No. 63 64, pp. 305 312, (1953)

11) Skempton: Geotechnique, Vol. 4, No. 4, p. 146 (1954)

12) Soderberg : Geotechnique, Vol. 12, p. 217 225(1962)

13) Pacheco Silva: Geotechnique, Vol. 3. p. 301 (1953) Skempton: Proc. ASCE, Vol. 80, Sep. No. 480, pp. 478-21, (1954)

14) Leonards : Foundation Engineering, p. 211 (1962)

15) Schmid : Proc 4th Int. Conf. Soil Mech., Vol. 3, p. 242 , (1957)

16) Tschebotarioff : Proc. 2nd Int. Conf. Soil Mech., Vol. 6, pp. 108 111 (1948)

Bishop : Proc. Brussels Conf. 58 on Earth Pressure Problems, Vol. 1, pp. 2, (1958)

17) Huizinga : Proc. 2 nd Int. Conf. Soil Mech., Vol.
6, p. 127 (1948)

Yang: Proc ASCE, Vol. 82, No. 1026 (1956)

18) Cummings 外: Proc. ASCE Vol. 74, pp. 1562 (1948)

19) Bjerrum 外: Norges Geoteknike Institutt, Publ. Nr. 28 , p. 10, (1958)

Bjerrum 外: Pore Pressure and Suction in Soils, Conf. (London), p. 109, (1960)

20) Reese 外: Proc. ASTM, Vol. 55, pp. 1156 1182 (1955)

21) Seed 外: Trans. ASCE, Vol. 122, p. 737 (1957); Proc. ASCE, No.842 (1955)

22) Soderberg : 上記 12) 最上武雄 : 土木学会, 最近の基礎工法, p. 39 (1962)

23） Reese 外：上記 20) Eide 外: Proc. 5 th Int. Conf. Soil Mech., Vol. 2, p. 52 (1961)

Mogami el : Proc. 5th Int. Conf. Soil Mech., Vol. 2, p. 114 (1961)

24) Soderman 外: Proc. 5th Int. Conf. Soil Mech. Vol. 2, p. 145 (1961)

25) 昭和 38 年度綜合 (特定) 研究, No. 95430 (代表 京都大 学 赤井浩一教授) の研究分担金より一部援助

(原稿受付 : 1963.4.16) 